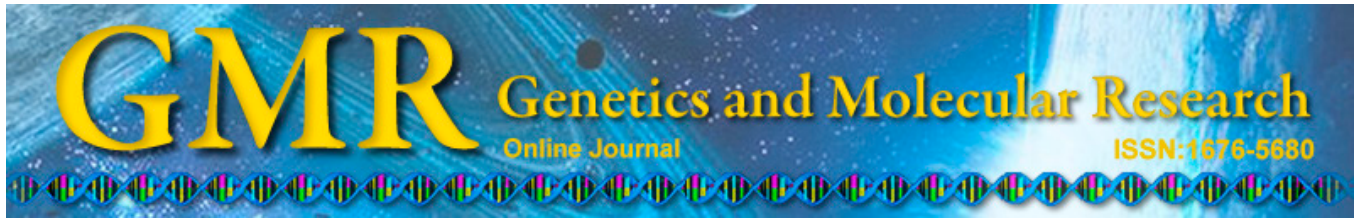

\title{
Association of MDR1 C3435T and C1236T single nucleotide polymorphisms with male factor infertility
}

\author{
S.E. Aydos ${ }^{1}$, A. Karadağํㅣ T. Özkan ${ }^{1}$, B. Altınok ${ }^{2}$, M. Bunsuz ${ }^{1}$, \\ S. Heidargholizadeh ${ }^{1}$, K. Aydos ${ }^{3}$ and A. Sunguroğlu ${ }^{1}$ \\ ${ }^{1}$ Department of Medical Biology, School of Medicine, Ankara University, \\ Ankara, Turkey \\ ${ }^{2}$ Vocational School of Health, Medical Laboratory Techniques, Ankara University, \\ Ankara, Turkey \\ ${ }^{3}$ Reproductive Health Research Center, School of Medicine, Ankara University, \\ Ankara, Turkey \\ Corresponding author: S.E. Aydos \\ E-mail: saydos@gmail.com
}

Genet. Mol. Res. 14 (2): 6330-6339 (2015)

Received October 1, 2014

Accepted March 26, 2015

Published June 11, 2015

DOI http://dx.doi.org/10.4238/2015.June.11.8

\begin{abstract}
Infertility affects 1 in 6 couples and approximately 1 in 25 men. Male factor infertility is a major cause of spermatogenic anomalies, the causes of which are largely unknown. Impaired reproductive functions in men might result from physiological, genetic, and/or environmental factors such as xenobiotics. The multi-drug resistancel $(M D R 1)$ gene encodes a P-glycoprotein which has a role in the active transport of various substrates providing protection of somatic cells from potentially toxic substances, including xenobiotics. MDR1 is highly expressed at the luminal surface of capillary endothelial cells, and is expressed in Leydig cells, testicular macrophages, and Sertoli cells. We performed genotype and haplotype analyses of MDR1 in 192 infertile and 102 fertile Turkish men for the genetic markers C1236T and C3435T, using polymerase chain
\end{abstract}


reaction-restriction fragment length polymorphism analysis. In the overall population, correlations were analyzed in all genotype models. We found that the C3435T polymorphism TT vs CT genotypes showed statistically significant differences in their association with infertility $(\mathrm{P}=0.045)$, and that the $\mathrm{CT}$ genotype was associated with high sperm DNA damage $(\mathrm{P}=0.02)$, suggesting that the $\mathrm{CT}$ genotype might be a susceptibility factor for infertility. Additionally, the T-T haplotype was significantly more frequent in the control group (13.2 vs $6.5 \%$; odds ratio $=0.459,95 \% \mathrm{CI}=0.259-0.814, \mathrm{P}=0.006$ ). This study showed that MDR1 might have a role in male infertility. Further research in large cohorts with different populations is required to clarify the role of MDR in male fertility.

Key words: Male infertility; MDR1 (ABCB1); Genetic polymorphism; P-glycoprotein

\section{INTRODUCTION}

Infertility is a common problem occurring with increasing frequency, affecting 1 in 6 couples and approximately 1 in 25 men. Genetic factors are suggested to have important roles in male factor infertility because of the pattern of familial aggregation of this disorder. However, possible genetic etiologies are still not well understood.

The multidrug resistance protein $1(M R P 1)$ gene encodes a transporter protein called Pglycoprotein (P-gp), which is a member of a family of proteins of which only one subgroup has a role in multidrug resistance (MDR). MDRl is highly expressed in cancer cells and plays a key role in anticancer and antiviral therapy. It is also constitutively expressed in excretory and barrier tissues, including those of the intestines, liver, kidneys, pancreas, brain, testes, and placenta. It has protective and eliminatory roles and protects organisms against toxic substances, including xenobiotics, by eliminating such compounds from cells and preventing their accumulation (Mizuno et al., 2003; Leslie et al., 2005; Loscher and Potschka, 2005; Miller et al., 2008).

In the human testes, although not expressed in mature germ cells, P-gp is highly expressed at the luminal surface of capillary endothelial cells, as well as in Leydig cells, testicular macrophages, and Sertoli cells, which provide for the protection of somatic cells from potentially toxic substances. P-gp has been suggested to affect the microenvironment of the seminiferous tubules by transporting testicular steroids (Melaine et al., 2002). P-gp transports many xenobiotics including pesticides, which are well-known factors that decrease male fertility (Bain and LeBlanc, 1996; Tielemens et al., 1999; Marzolini et al., 2004).

The highly polymorphic MDRl gene is characterized by several single nucleotide polymorphisms (SNPs). The C3435T SNP in exon 26 of MDR1 is a silent yet extensively studied polymorphism that is associated with low P-gp expression in enterocytes and peripheral blood mononuclear cells (PBMCs) (Owen et al., 2004). This SNP has an effect on both the expression and function of the P-gp protein (Hoffmeyer et al., 2000). In individuals homozygous for the T-allele, P-gp displays a low expression in intestinal and PBMCs, whereas homozygosity for the $\mathrm{C}$-allele is associated with increased P-gp expression (Brinkmann et al., 2001).

The C3435T polymorphism (exon 26, C $>$ T, Ile 1145 Ile) presents strong linkage disequilibrium with the C1236T synonymous SNP on exon 12 (C>T, Gly 412 Gly) (Kim et al., 
2001). These represent the most extensively analyzed synonymous MDR1 SNPs for different diseases. Investigation of the genetic variations of the $M D R 1$ gene in diseases bears significance for the interpretation of the consequences such polymorphisms generate for P-gp function and disease etiology.

To our knowledge, although several studies exist on the association of diseases, including lung cancer, AML, colorectal cancer, esophageal cancer, inflammatory bowel disease (IBW), and Parkinson's disease (Tan et al., 2005; Annese et al., 2006; Gervasini et al., 2006; Kim et al., 2006; Komoto et al., 2006, Huebner et al., 2009; Balcerczak et al., 2010) with $M D R$ polymorphisms, only one study is available on the association of the MDR1 $3435 \mathrm{C}>\mathrm{T}$ polymorphism with male infertility, based on a Polish population (Drodźik et al., 2009). In our study we aimed to analyze the MDRl SNPs $3435 \mathrm{C}>\mathrm{T}$ and $1236 \mathrm{C}>\mathrm{T}$ in the Turkish male infertile population.

\section{MATERIAL AND METHODS}

We recruited 192 men with primary infertility and impaired seminal parameter(s) (mean age 32 years, range 25-41 years), known to have not achieved a pregnancy within at least one year of unprotected intercourse. A full clinical evaluation, including medical and reproductive history and physical examination of the genitals, was performed on the subjects. A minimum of two consecutive semen analyses were performed following a sexual abstinence of 3-5 days, in accordance with published criteria (World Health Organization, 2010). Each of the subjects presented with a history of infertility, lacking any indication of possible hormonal, infective, or physical causes. The only defect their clinical evaluation pointed out was the presence of one or more of the abnormal seminal parameters (density, motility, and/or morphology), referred to as male factor infertility. For the adjustment of the results, the subjects were questioned regarding their smoking habits, considering that it is the most common and influential health risk factor for this disorder. The subjects declaring to have more than one cigarette daily were considered smokers (Pasqualotto et al., 2006). Peripheral blood karyotype and $\mathrm{Y}$ chromosome analyses were performed by standard techniques in infertile subjects. The presence of varicoceles was clinically assessed based on genital examination by an infertility specialist (K.A.) and in suspected cases confirmed by a color Doppler ultrasound examination of the scrotum. Subjects detected to have varicocele, Y chromosome deletions, abnormal karyotypes, hypogonadotropic hypogonadism, or seminal tract obstructions were not included in the study. The history of their female partners was also recorded. General, systemic, and local clinical examinations were performed. The female partners of all the infertile men included in this study were investigated thoroughly and found to be healthy.

In the patient group of 100 infertile men whose sperm parameters were known, the genotyping results were found to be correlated with both the seminal parameters and the sperm DNA fragmentation results. The control group consisted of 102 healthy unrelated volunteers having at least one child without any assisted reproductive methods, revealing no medical history of cancer or other chronic diseases. The blood samples of the control group (mean age 36 years, range 27-47 years) were obtained from the Blood Banking Services of Ankara University. All the patients and controls were of Turkish ethnicity.

The study was approved by the Institutional Ethical Committee of Ankara University Faculty of Medicine (approval number 14-316), and written informed consent was obtained from all subjects who participated in the study. 


\section{Genotyping of MDR1 polymorphisms}

The genomic DNA samples used for polymorphic analyses were extracted from donor lymphocytes, using a standard method (Sambrook et al., 1982). MDR1 genotyping was performed by polymerase chain reaction (PCR)-based restriction fragment length gene polymorphism. DNA amplification was performed under similar conditions for each polymorphism with the use of PCR buffer (MBI Fermentas, St Leon-Rot, Germany), $25 \mathrm{mM}$ magnesium chloride (MBI Fermentas), $2.5 \mathrm{mM}$ of each deoxyribonucleoside triphosphate (Sigma, St. Louis, MO, USA), $600 \mathrm{mg} / \mathrm{mL}$ DNA, $100 \mathrm{ng} / \mathrm{mL}$ of each specified primer (Iontek, Turkey), $0.5 \mathrm{mU}$ Taq DNA polymerase (MBI Fermentas) in a total volume of $50 \mathrm{~mL}$. After an initial denaturation at $94^{\circ} \mathrm{C}$ for $5 \mathrm{~min}, 35$ cycles of $45 \mathrm{~s}$ at $94^{\circ} \mathrm{C}, 45 \mathrm{~s}$ at $57^{\circ}-60^{\circ} \mathrm{C}, 1 \mathrm{~min}$ at $72^{\circ} \mathrm{C}$, and a final extension period of $5 \mathrm{~min}$ at $72^{\circ} \mathrm{C}$ were carried out in a Corbett thermal cycler (Corbett Research, Sydney, Australia). Primer sequences, restriction enzymes, and fragment lengths are given in Table 1. DNA fragments generated were separated on a $3 \%$ NuSieve agarose gel. After the gel was stained with ethidium bromide $(0.5 \mathrm{mg} / \mathrm{mL})$, restriction fragments were visualized under a UV transilluminator.

\begin{tabular}{|c|c|c|c|c|}
\hline SNP & Primers & $\begin{array}{l}\text { Restriction } \\
\text { enzymes }\end{array}$ & $\begin{array}{l}\text { Digestion } \\
\text { conditions }\end{array}$ & $\begin{array}{l}\text { PCR product and } \\
\text { restriction fragment sizes }\end{array}$ \\
\hline $\mathrm{C} 1236 \mathrm{~T}$ & $\begin{array}{l}\text { F: 5'-TAT CCT GTG TCT GTG AAT TGC C-3' } \\
\text { R: 5'-CCT GAC TCA CCA CAC CAA TG-3' }\end{array}$ & HaeIII & $37.8^{\circ} \mathrm{C}$ for $16 \mathrm{~h}$ & $\begin{array}{l}\text { PCR: } 366 \text { bp, C allele: } \\
269,62 \text {, and } 35 \text { bp, T allele: } \\
269 \text { and } 97 \mathrm{bp}\end{array}$ \\
\hline C3435T & $\begin{array}{l}\text { F: 5'-TGT TTT CAG CTG CTT GAT GG-3' } \\
\text { R: 5'-AAG GCA TGT ATG TTG GCC TC-3' }\end{array}$ & Sau3AI & $37.8^{\circ} \mathrm{C}$ for $16 \mathrm{~h}$ & $\begin{array}{l}\text { PCR: } 197 \mathrm{bp}, \text { C allele: } 158 \\
\text { and } 39 \mathrm{bp}, \text { T allele: } 197 \mathrm{bp}\end{array}$ \\
\hline
\end{tabular}

$\mathrm{SNP}=$ single nucleotide polymorphism; $\mathrm{PCR}=$ polymerase chain reaction.

\section{Determination of sperm DNA damage using the comet assay}

After undergoing a freeze-thaw cycle, semen samples were analyzed using the comet assay. The comet assay was performed on 102 semen samples obtained from male patients with infertility. Sperm DNA fragmentation was assessed using the single-cell gel electrophoresis (Comet) assay, as modified by Singh et al. (1988). Sperm cells stained with ethidium bromide were visualized under a fluorescence microscope (Olympus LX51, Olympus, Tokyo, Japan). Each cell with fragmented DNA had the appearance of a comet with a brightly fluorescent head and a tail to one side formed by the DNA, which contained strand breaks that were drawn away during electrophoresis. At least 300 sperm were counted for each sample. Each image was classified according to the intensity of the fluorescence in the comet tail and given a value of $0,1,2$, 3 , or 4 [from undamaged (class 0 ) to maximally damaged (class 4)], such that the total score of the slide would be between 0 and 400 arbitrary units (Gulum et al., 2011).

\section{Statistical analyses}

Continuous variables are reported as median (minimum-maximum) and means \pm standard deviation. The Kruskal-Wallis test was used to compare the genotype groups for sperm DNA damage, classified as undamaged, low-damaged, moderately damaged, damaged, 
or highly damaged. When the P value resulting from the Kruskal-Wallis test was significant, pairwise comparisons were performed. Allele and genotype frequencies of the patients with infertility and controls were compared with the chi-square test and the Fisher exact test, where applicable. Data analyses were performed using IBM SPSS Statistics v.20 (SPSS, Chicago, IL, USA). A P value $<0.05$ was considered as statistically significant. Allele, genotype, and haplotype frequencies, consistency with Hardy-Weinberg equilibrium (HWE), and linkage disequilibrium were analyzed with the SHEsis software (Shi and He, 2005).

\section{RESULTS}

In this study, we compared the infertile and the fertile control groups for the same two SNPs on the MDR1 gene. The frequencies of the $\mathrm{C}$ and $\mathrm{T}$ alleles of the 1236 locus were found to be $61.2 \%(\mathrm{~N}=235), 38.8 \%(\mathrm{~N}=149)$; and $59.8 \%(\mathrm{~N}=122), 40.2 \%(\mathrm{~N}=82)$, in the infertile and the control groups, respectively. The $\mathrm{C}$ allele was detected more frequently in the patient group, although the difference was not significant $(\mathrm{P}>0.05)$. The frequencies of the MDR1 $1236 \mathrm{CC}, \mathrm{CT}$, and TT genotypes were $34.4 \%(\mathrm{~N}=66), 53.6 \%(\mathrm{~N}=103), 12 \%(\mathrm{~N}=$ $23)$, in the infertile group; and $34.3 \%(\mathrm{~N}=35), 51 \%(\mathrm{~N}=52), 14.7 \%(\mathrm{~N}=15)$ in the control group, respectively. However, the observed genotype frequencies did not show significant differences in either group $(\mathrm{P}>0.05)$. The genotype frequency distribution of the 1236 locus was consistent with HWE in both groups $(\mathrm{P}>0.05)$ (Table 2).

Table 2. Comparison of the genotype frequencies of the C3435T and C1236T loci between patients with infertility and controls.

\begin{tabular}{|c|c|c|c|c|c|c|c|c|c|c|c|c|c|}
\hline SNP & Genotype & $\begin{array}{l}\text { Patients } \\
\mathrm{N} \text { (freq) }\end{array}$ & $\begin{array}{l}\text { Controls } \\
\mathrm{N} \text { (freq) }\end{array}$ & $\chi^{2}$ & $\begin{array}{l}\text { Global } \\
\text { P value }\end{array}$ & $\begin{array}{l}\text { P value for } \\
\text { patient HWE }\end{array}$ & $\begin{array}{l}\text { P value for } \\
\text { control HWE }\end{array}$ & Allele & $\begin{array}{l}\text { Patients } \\
\mathrm{N} \text { (freq) }\end{array}$ & $\begin{array}{l}\text { Controls } \\
\mathrm{N} \text { (freq) }\end{array}$ & $\chi^{2}$ & $\begin{array}{l}\text { Global } \\
\text { P value }\end{array}$ & $\begin{array}{l}\text { Odds ratio } \\
(95 \% \mathrm{CI})\end{array}$ \\
\hline \multirow[t]{3}{*}{$\mathrm{C} 1236 \mathrm{~T}$} & $\mathrm{CC}$ & $66(0.34)$ & $35(0.34)$ & 0.473 & 0.789 & $0.02 *$ & 0.845 & $\mathrm{C}$ & $235(0.61)$ & $122(0.59)$ & 0.108 & 0.741 & $1.060(0.749-1.499)$ \\
\hline & CT & $103(0.53)$ & $52(0.51)$ & & & & & $\mathrm{T}$ & $149(0.38)$ & $82(0.40)$ & & & \\
\hline & TT & $23(0.12)$ & $15(0.14)$ & & & & & & & & & & \\
\hline \multirow[t]{3}{*}{ C3435T } & $\mathrm{CC}$ & $53(0.27)$ & $27(0.26)$ & 4.077 & 0.130 & 0.07 & 0.542 & $\mathrm{C}$ & $216(0.56)$ & $104(0.51)$ & 1.491 & 0.221 & $1.23(0.879-1.737)$ \\
\hline & $\mathrm{CT}$ & $110(0.57)$ & $50(0.49)$ & & & & & $\mathrm{T}$ & $168(0.43)$ & $100(0.49)$ & & & \\
\hline & TT & $29(0.15)$ & $25(0.24)$ & & & & & & & & & & \\
\hline
\end{tabular}

HWE $\mathrm{P}$ values were calculated using the SHEsis program. SNP = single nucleotide polymorphism; Freq $=$ frequency; $\mathrm{HWE}=$ Hardy-Weinberg equilibrium; $\mathrm{CI}=$ confidence interval. *Significant $\mathrm{P}$ value.

The $\mathrm{C}$ and $\mathrm{T}$ allele frequencies at the 3435 locus were found to be $56.2 \%(\mathrm{~N}=216)$, $43.8 \%(\mathrm{~N}=168)$; and $51 \%(\mathrm{~N}=104), 49 \%(\mathrm{~N}=100)$, in the infertile and the control groups, respectively. The differences between the infertile patient and the control groups were statistically insignificant $(\mathrm{P}>0.05)$. The frequencies of the MDR1 $3435 \mathrm{CC}, \mathrm{CT}$, and TT genotypes were $27.6 \%(\mathrm{~N}=53), 57.3 \%(\mathrm{~N}=110), 15.1 \%(\mathrm{~N}=29)$, in the infertile group; and $26.5 \%(\mathrm{~N}=$ $27), 49 \%(\mathrm{~N}=50), 24.5 \%(\mathrm{~N}=25)$, in the control group, respectively (Table 2$)$. The observed genotype frequencies did not show any significant difference in either group $(\mathrm{P}>0.05)$. The frequency of the $3435 \mathrm{CT}$ genotype was higher but statistically insignificant in the infertile group $(\mathrm{P}>0.05)$. The genotype frequency distribution of the 3435 locus was consistent with HWE in the control group; however, it showed significant deviation from the HWE in the infertile group $(\mathrm{P}=0.07)$.

The haplotype frequencies of the 1236 and 3435 loci are presented in Table 3. Each of the four possible haplotypes was noted in both the infertile and control groups. When the 
frequency distributions of the estimated haplotypes were compared between the infertile and control groups, the frequency of the T-T haplotype was found to be significantly higher in the control group than in the infertile group [13.2 vs $6.5 \%$, odds ratio $(\mathrm{OR})=0.459, \mathrm{P}=0.006]$.

Table 3. Haplotype analysis for the C1236T and C3435T polymorphic loci using the SHEsis software.

\begin{tabular}{lccccrr}
\hline Haplotype & Patients [N (freq); total = 384] & Controls [N (freq); total = 204] & $\chi^{2}$ & Fisher's P & Pearson's P & Odds ratio (95\%CI) \\
\hline C-C & $92(0.240)$ & $48(0.240)$ & 0.000 & 0.998 & 0.998 & $1.000(0.672-1.488)$ \\
C-T & $123(0.323)$ & $55(0.270)$ & 1.750 & 0.185 & 0.185 & $1.288(0.885-1.876)$ \\
T-C & $142(0.372)$ & $73(0.358)$ & 0.112 & 0.737 & 0.737 & $1.062(0.746-1.512)$ \\
T-T & $25(0.065)$ & $26(0.132)$ & 7.361 & $0.006^{*}$ & 0.006 & $0.459(0.259-0.814)$ \\
\hline
\end{tabular}

$\mathrm{d}^{\prime}: 0.503, \mathrm{r}^{2}: 0.137 . \mathrm{CI}=$ confidence interval. *Significant $\mathrm{P}$ value.

We investigated the correlation between the MDR1 C3435T and C1236T polymorphisms and the risk of infertility. In the overall population, the correlation was analyzed in all genotype models (Table 4). We found that only the TT vs CT genotype comparison showed statistically significant differences in terms of association between the C3435T polymorphism and infertility $(\mathrm{P}=0.045)$; there were no other significant differences between the groups. Our results indicated that the CT genotype might be a susceptibility factor for infertility and that the $\mathrm{CT}$ genotype was associated with high levels of sperm DNA damage $(\mathrm{P}=0.02)$ (Table 5).

Table 4. Correlation of the MDRI C3435T and C1236T polymorphisms with the risk of infertility.

\begin{tabular}{llccc}
\hline & & OR & $(95 \%$ CI & P value \\
\hline C3435T & CT vs CC & 1.21 & $0.633-1.985$ & 0.696 \\
& TT vs CC & 0.591 & $0.291-1.99$ & 0.144 \\
& TT vs CT & 1.897 & $1.010-3.56$ & $0.045^{*}$ \\
TT+CT vs CC & 0.944 & $0.549-1.623$ & 0.835 \\
C1236T & CT vs CC & 1.050 & $0.619-1.782$ & 0.855 \\
& TT vs CC & 0.813 & $0.377-1.754$ & 0.598 \\
& TT vs CT & 1.292 & $0.622-2.681$ & 0.492 \\
& TT+CT vs CC & 0.997 & $0.601-1.654$ & 0.992 \\
\hline
\end{tabular}

$\mathrm{OR}=$ odds ratio $; \mathrm{CI}=$ confidence interval. *Significant $\mathrm{P}$ value.

Table 5. Correlation of the genotypes of the C3435T and C1236T loci with the total comet assay score.

\begin{tabular}{llcccc}
\hline SNP & & CC & CT & TT & P value \\
\hline C3435T & Mean \pm SD & $182.8 \pm 53.8$ & $215.2 \pm 52.8^{*}$ & $166.5 \pm 68.7$ & $0.02^{*}$ \\
& Med & 180.7 & 206.7 & 153.5 & \\
& (Min-Max) & $(86.9 \pm 305.5)$ & $(133.6 \pm 382.6)^{*}$ & $(62.8 \pm 265.5)$ & 0.587 \\
C1236T & Mean \pm SD & $193.3 \pm 55.2$ & $204.6 \pm 59.3$ & $195.0 \pm 57.1$ & 192.7 \\
& Med & 201.5 & 205.2 & $(142.0 \pm 256.3)$ & \\
\hline
\end{tabular}

$\mathrm{SNP}=$ single nucleotide polymorphism; $\mathrm{SD}=$ standard deviation; med = median; $\min =$ minimum; $\max =$ maximum. *Significant $\mathrm{P}$ value.

In this survey, binary genotypic analysis was carried out for the nine potential combinations of the two loci (Table 6). In both the infertile patient and control groups, CC-CT, CT-CC, and CT-CT were detected as the three most common genotype combinations with frequencies of $19.3,19.8$, and $31.8 \%$ in the infertile group, and $16.7,16.7$, and $27.5 \%$ in the control group, respectively. Genotype combinations from the two SNPs did not significantly differ between the infertile and fertile groups $(\mathrm{P}=0.357)$. 
Table 6. Comparative analysis of binary genotypes observed for the MDR1 C3435T-C1236T loci in the patients with infertility and controls.

\begin{tabular}{|c|c|c|c|c|c|c|}
\hline \multirow[t]{2}{*}{ Genotypes } & \multicolumn{2}{|c|}{ Patients } & \multicolumn{2}{|c|}{ Controls } & \multirow[t]{2}{*}{$P$ value } & \multirow[t]{2}{*}{ OR $(95 \% \mathrm{CI})$} \\
\hline & $\mathrm{N}$ & Frequency & $\mathrm{N}$ & Frequency & & \\
\hline CC-CC & 5 & 0.0260 & 4 & 0.0392 & 0.724 & $1.524(0.401-5.814)$ \\
\hline CC-CT & 37 & 0.1927 & 17 & 0.1666 & 0.583 & $0.838(0.445-1.577)$ \\
\hline CC-TT & 11 & 0.0572 & 6 & 0.0588 & 0.957 & $1.028(0.369-2.866)$ \\
\hline CT-CC & 38 & 0.1979 & 17 & 0.1666 & 0.513 & $0.811(0.431-1.522)$ \\
\hline CT-CT & 61 & 0.3177 & 28 & 0.2745 & 0.443 & $0.813(0.487-1.381)$ \\
\hline CT-TT & 11 & 0.0572 & 5 & 0.0490 & 0.766 & $0.848(0.286-0.251)$ \\
\hline TT-CC & 23 & 0.1197 & 14 & 0.1372 & 0.667 & $1.169(0.573-2.386)$ \\
\hline TT-CT & 5 & 0.0260 & 7 & 0.0686 & 0.118 & $2.754(0.851-8.928)$ \\
\hline TT-TT & 1 & 0.0052 & 14 & 0.0392 & 0.051 & $7.812(0.859-7.1428)$ \\
\hline
\end{tabular}

$\mathrm{OR}=$ odds ratio $\mathrm{CI}=$ confidence interval.

We investigated 100 infertile men whose semen parameters were known to analyze the effects of the C3435T and C1236T polymorphisms on sperm parameters (morphology, motility, and concentration) and DNA fragmentation. No correlation was found to exist between polymorphisms of the MDR1 gene and sperm morphology, motility, or concentration (Table 7). However, the $3435 \mathrm{CT}$ genotype was determined to be correlated with increased DNA damage levels of sperm $(\mathrm{P}<0.05)$ (Table 5).

Table 7. Correlation of the genotypes of the C3435T and C1236T loci with sperm parameters.

\begin{tabular}{|c|c|c|c|c|c|c|}
\hline & \multicolumn{3}{|c|}{$\mathrm{C} 3435 \mathrm{~T}$} & \multicolumn{3}{|c|}{$\mathrm{C} 1236 \mathrm{~T}$} \\
\hline & $\mathrm{CC}$ & $\mathrm{CT}$ & TT & $\mathrm{CC}$ & $\mathrm{CT}$ & TT \\
\hline \multicolumn{7}{|l|}{ Sperm count } \\
\hline$\geq 15$ million $/ \mathrm{mL}$ & $13(44.8 \%)$ & $23(38.3 \%)$ & $5(45.5 \%)$ & $16(47.1 \%)$ & $23(37.1 \%)$ & $2(50.0 \%)$ \\
\hline \multirow[t]{2}{*}{$<15$ million $/ \mathrm{mL}$} & $16(55.2 \%)$ & $37(61.7 \%)$ & $6(54.5 \%)$ & $18(52.9 \%)$ & $39(62.9 \%)$ & $2(50.0 \%)$ \\
\hline & & $\mathrm{P}$ value 0.802 & & & $P$ value 0.594 & \\
\hline \multicolumn{7}{|l|}{ Progressive Motility } \\
\hline$\geq 32 \%$ & $16(55.2 \%)$ & $32(53.3 \%)$ & $8(72.7 \%)$ & $20(58.8 \%)$ & $34(54.8 \%)$ & $2(50.0 \%)$ \\
\hline$<32 \%$ & $13(44.8 \%)$ & $28(46.7 \%)$ & $3(27.3 \%)$ & $14(41.2 \%)$ & $28(45.2 \%)$ & $2(50.0 \%)$ \\
\hline \multicolumn{7}{|l|}{ Kruger } \\
\hline$\geq 4 \%$ & $3(10.3 \%)$ & $13(21.7 \%)$ & $5(45.5 \%)$ & $9(26.5 \%)$ & $11(17.7 \%)$ & $1(25.0 \%)$ \\
\hline \multirow[t]{2}{*}{$<4 \%$} & $26(89.7 \%)$ & $47(78.3 \%)$ & $6(54.5 \%)$ & $25(73.5 \%)$ & $51(82.3 \%)$ & $3(75.0 \%)$ \\
\hline & & $P$ value 0.051 & & & $P$ value 0.592 & \\
\hline
\end{tabular}

\section{DISCUSSION}

Several studies have reported that both the quality and quantity of human semen have significantly decreased over the past decades (Geoffroy-Siraudin et al., 2012). The underlying reasons remain unknown. Many environmental, physiologic, and genetic factors may impair reproductive functions in men. Among the environmental factors, xenobiotics have been shown to play a significant role. Biologically active xenobiotics produce adverse effects by means of covalent interactions between intermediate metabolites and cellular macromolecules, including DNA and protein. Xenobiotics act as substrates for P-gp, which is produced by the MDR1 $(A B C B 1)$ gene. P-gp is found in the blood-testis barrier and protects the testes by preventing the penetration of xenobiotics. Mdrla (-/-) knockout mice have been shown to accumulate more P-gp substrates (e.g., ivermectin, vinblastine, and nelfinavir) within the testicular tissue than do wild-type controls (Schinkel, 1997; Choo et al., 2000). 
Genetic polymorphisms of the MDR1 gene were first identified by Kioka et al. (1989) Alterations in P-gp expression and function potentially depend on variations of the MDR1 nucleotide sequence. The most commonly reported MDRI SNPs in the P-gp are the synonymous SNPs 1236 (exon 12, C>T, Gly 412 Gly) and 3435 (exon 26, C>T, Ile 1145 Ile). Although the $\mathrm{C} 3435 \mathrm{~T}$ mutation is a silent mutation, this polymorphism affects the expression and function of the P-gp. The C3435T polymorphism presents strong linkage disequilibrium with the C1236T synonymous SNP on exon 12 (Kim et al., 2001). MDR1 expression is highly variable between subjects. This variability demonstrates that the interethnic diversity and genetic polymorphism of the MDR1 gene is associated with a variation in expression level (Hoffmeyer et al., 2000; Taniguchi et al., 2003; Meissner et al., 2004).

Only one study has been published on the association of the MDR1 $3435 \mathrm{C}>\mathrm{T}$ polymorphism with male infertility, which was carried out in the Polish population by Droździk et al. (2009). In this study, only the relation between the MDR1 $3435 \mathrm{C}>\mathrm{T}$ polymorphism and male infertility was analyzed. In the present study, we investigated the correlation between male infertility and both MDR1 gene C1236T and C3435T polymorphisms, along with their haplotypes and binary genotypes. Both studies are based on the assumption that MDR1 SNPs are associated with lower P-gp expression in the testes, leading to damage of the testes and eventually infertility. Droździk et al. (2009) reported that the risk of infertility was significantly elevated (two-fold) in individuals carrying at least one $\mathrm{T}$ allele, including individuals of the $3435 \mathrm{TT}$ and 3435CT genotypes. As the MDRI T allele was previously associated with lower P-gp activity, these results were interpreted as an indication of this allele possibly being related to the increased testicular penetration of xenobiotics. These results suggested that individuals carrying a $\mathrm{T}$ allele might be more prone to developing infertility. However, our results showed that the frequencies of the MDR1 $3435 \mathrm{CT}$ and TT genotypes among infertile and fertile subjects were 72.4 and $73.5 \%$, respectively. Thus, we found no differences between the fertile and infertile groups in contrast to those seen in the Polish population. The difference between the results of the two studies might be due to interethnic diversity as well as due to the possibility that the observed association of the MDR1 3435T allele with infertility in the study of Droździk et al. (2009) might represent a false positive, as they indicated in the article. Furthermore, the frequency of MDR1 3435C > T genotypes among the control group of fertile men in the Droździk et al. study differed from published data for healthy controls from the same region (Kurzawski et al., 2006). Therefore, the significance of their results might arise from an overrepresentation of 3435CC homozygotes among the controls, as they suggested (Droździk et al., 2009).

We found that only the TT vs CT genotype comparison showed statistically significant differences $(\mathrm{P}=0.045)$ in terms of association between the $\mathrm{C} 3435 \mathrm{~T}$ polymorphism and infertility (Table 4), and that there were no other significant differences between the groups. We also showed that the CT genotype was associated with high levels of sperm DNA damage. This result also supported the association between the CT genotype and infertility risk. In a study carried out by Rüstemoğlu et al. (2011) the CT genotype was also observed more frequently in the patient familial mediterranean fever group. It was suggested that the CT genotype might be a susceptibility factor for the disease phenotype. According to our result, we also suggested that the CT genotype might be a susceptibility factor for infertility. BektaşKayhan et al. (2012) also described that children with acute lymphoblastic leukemia carrying the CT genotype are more prone to develop oral mucositis and might therefore also be more susceptible to the side effects of chemotherapy.

In the Polish population, no correlation was found between the MDR1 C3435T poly- 
morphism and sperm parameters. Similarly, we did not find any correlation between the MDRI SNPs 3435 or 1236 and sperm parameters. However, the CT genotype at the C3435T locus was more common in infertile men with high levels of sperm DNA damage $(\mathrm{P}=0.02)$.

The frequencies of the MDRI 1236 and 3435 alleles and genotypes determined in our control group were in agreement with those reported in previous studies conducted in the Turkish population (Gümüş-Akay et al., 2010, Dogu et al., 2012; Rüstemoğlu et al., 2012).

Recent studies have demonstrated that inconsistencies might be better understood by grouping SNPs into haplotypes and this method might be used to predict the functional consequences of MDR1 polymorphisms (Kimchi-Sarfaty et al., 2007). Our results showed that the frequency of the T-T haplotype was significantly higher in the control group (13.2 vs 6.5\%; $\mathrm{OR}=0.459,95 \%$ confidence interval $=0.259-0.814, \mathrm{P}=0.006$ ). Our data could be interpreted to mean that the T-T haplotype might serve as a protective factor for the infertility phenotype, as the frequency of this haplotype was found to be significantly lower in infertile men than in fertile controls (Table 3).

Our findings could indicate a new predictor of fertility. Further studies are required in a large series of different populations to clarify the role of MDR variation on male fertility.

\section{Conflicts of interest}

The authors declare no conflict of interest.

\section{ACKNOWLEDGMENTS}

We thank Zeynep Biyikli Gencturk for assistance statistical analysis.

\section{REFERENCES}

Annese V, Valvano MR, Palmieri O, Latiano A, et al. (2006). Multidrug resistance 1 gene in inflammatory bowel disease: a meta-analysis. World J. Gastroenterol. 12: 3636-3644.

Bain LJ and LeBlanc GA (1996). Interaction of structurally diverse pesticides with the human MDRI gene product P-glycoprotein. Toxicol. Appl. Pharmacol. 141: 288-298.

Balcerczak E, Panczyk M, Piaskowski S, Pasz-Walczak G, et al. (2010). ABCB1/MDR1 gene polymorphisms as a prognostic factor in colorectal cancer. Int. J. Colorectal Dis. 25: 1167-1176.

Bektaş-Kayhan K, Küçükhüseyin Ö, Karagöz G, Ünür M, et al. (2012). Is the MDRl C3435T polymorphism responsible for oral mucositis in children with acute lymphoblastic leukemia? Asian Pac. J. Cancer Prev. 13: 5251-5255.

Brinkmann U, Roots I and Eichelbaum M (2001). Pharmacogenetics of the human drug-transporter gene MDR1: impact of polymorphisms on pharmacotherapy. Drug Discov. Today 6: 835-839.

Choo EF, Leake B, Wandel C, Imamura H, et al. (2000). Pharmacological inhibition of P-glycoprotein transport enhances the distribution of HIV-1 protease inhibitors into brain and testes. Drug Metab. Dispos. 28: 655-660.

Dogu GG, Kargi A, Turgut S, Ayada C, et al. (2012). MDR1 single nucleotide polymorphism C3435T in Turkish patients with non-small-cell lung cancer. Gene 506: 404-407.

Droździk M, Stefankiewicz J, Kurzawa R, Górnik W, et al. (2009). Association of the MDR1 (ABCB1) gene 3435C >T polymorphism with male infertility. Pharmacol. Rep. 61: 690-696.

Geoffroy-Siraudin C, Loundou AD, Romain F, Achard V, et al. (2012). Decline of semen quality among 10932 males consulting for couple infertility over a 20-year period in Marseille, France. Asian J. Androl. 14: 584-590.

Gervasini G, Carrillo JA, Garcia M, San Jose C, et al. (2006). Adenosine triphosphate-binding cassette B1 (ABCB1) (multidrug resistance 1) G2677T/A gene polymorphism is associated with high risk of lung cancer. Cancer 107: 2850-2857.

Gulum M, Yeni E, Kocyigit A, Taskin A, et al. (2011). Sperm DNA damage and seminal oxidative status after shock-wave lithotripsy for distal ureteral stones. Fertil. Steril. 96: 1087-1090. 
Gümüş-Akay G, Rüstemoğlu A, Karadağ A and Sunguroğlu A (2010). Haplotype-based analysis of MDR1/ABCB1 gene polymorphisms in a Turkish population. DNA Cell Biol. 29: 83-90.

Hoffmeyer S, Burk O, Richter O, Arnold HP, et al. (2000). Functional polymorphisms of the human multidrug-resistance gene: multiple sequence variations and correlation of one allele with P-glycoprotein expression and activity in vivo. Proc Natl. Acad. Sci. U.S.A. 97: 3473-3478.

Huebner C, Browning BL, Petermann I, Han DY, et al. (2009). Genetic analysis of MDR1 and inflammatory bowel disease reveals protective effect of heterozygous variants for ulcerative colitis. Inflamm. Bowel Dis. 15: 1784-1793.

Kim DH, Park JY, Sohn SK, Lee NY, et al. (2006). Multidrug resistance-1 gene polymorphisms associated with treatment outcomes in de novo acute myeloid leukemia. Int. J. Cancer 118: 2195-2201.

Kim RB, Leake BF, Choo EF, Dresser GK, et al. (2001). Identification of functionally variant MDRl alleles among European Americans and African Americans. Clin. Pharmacol. Ther. 70: 189-199.

Kimchi-Sarfaty C, Oh JM, Kim IW, Sauna ZE, et al. (2007). A "silent" polymorphism in the MDR1 gene changes substrate specificity. Science 315: 525-528.

Kioka N, Tsubota J, Kakehi Y, Komano T, et al. (1989). P-glycoprotein gene (MDR1) cDNA from human adrenal: normal P-glycoprotein carries Gly185 with an altered pattern of multidrug resistance. Biochem Biophys Res Commun. 162: 224-31.

Komoto C, Nakamura T, Sakaeda T, Kroetz DL, et al. (2006). MDRl haplotype frequencies in Japanese and Caucasian, and in Japanese patients with colorectal cancer and esophageal cancer. Drug Metab. Pharmacokinet. 21: 126-132.

Kurzawski M, Pawlik A, Górnik W, Drozdzik M (2006). Frequency of common MDRl gene variants in a Polish population. Pharmacol. Rep. 58: 35-40.

Leslie EM, Deeley RG and Cole SP (2005). Multidrug resistance proteins: role of P-glycoprotein, MRP1, MRP2, and BCRP (ABCG2) in tissue defense. Toxicol. Appl. Pharmacol. 204: 216-237.

Löscher W and Potschka H (2005). Blood-brain barrier active efflux transporters: ATP-binding cassette gene family. NeuroRx. 2: 86-98.

Marzolini C, Paus E, Buclin T and Kim R (2004). Polymorphism in human MDR1 (P-glycoprotein), recent advances and clinical relevance. Clin. Pharmacol. Ther. 75: 13-33.

Meissner K, Jedlitschky G, Meyer zu Schwabedissen H, Dazert P, et al. (2004). Modulation of multidrug resistance P-glycoprotein 1 (ABCB1) expression in human heart by hereditary polymorphisms. Pharmacogenetics 14: 381-385.

Melaine N, Liénard MO, Dorval I, Le Goascogne C, et al. (2002). Multidrug resistance genes and p-glycoprotein in the testis of the rat, mouse, guinea pig and human. Biol. Reprod. 67: 1699-1707.

Miller DS, Bauer B and Hartz AM (2008). Modulation of P-glycoprotein at the blood-brain barrier: opportunities to improve central nervous system pharmacotherapy. Pharmacol. Rev. 60: 196-209.

Mizuno N, Niwa T, Yotsumoto Y and Sugiyama Y (2003). Impact of drug transporter studies on drug discovery and development. Pharmacol. Rev. 55: 425-461.

Owen A, Chandler B, Bray PG, Ward SA, et al. (2004). Functional correlation of P-glycoprotein expression and genotype with expression of the human immunodeficiency virus type 1 coreceptor CXCR4. J. Virol. 78: 12022-12029.

Pasqualotto FF, Sobreiro BP, Hallak J, Pasqualotto EB, et al. (2006). Cigarette smoking is related to a decrease in semen volume in a population of fertile men. BJU Int. 97: 324-326.

Rüstemoğlu A, Gumus-Akay G, Yigit S and Tasliyurt T (2011). Analysis of common MDRl (ABCB1) gene C1236T and C3435T polymorphisms in Turkish patients with familial Mediterranean fever. Genet. Mol. Res. 10: 3411-3420.

Rüstemoğlu A, Gül Ü, Gümüş-Akay G, Gönül M, et al. (2012). MDRl gene polymorphisms may be associated with Behçet's disease and its colchicum treatment response. Gene 505: 333-339.

Sambrook J, Fritsch EF and Maniatis T (1982). Molecular cloning: a laboratory manual. 2nd ed. Cold Spring Harbor Laboratory Press, Cold Spring Harbor, 458-462.

Schinkel AH (1997). The physiological function of drug-transporting P-glycoproteins. Semin. Cancer Biol. 8: 161-170.

Shi YY and He L (2005). SHEsis, a powerful software platform for analyses of linkage disequilibrium, haplotype construction, and genetic association at polymorphism loci. Cell Res. 15: 97-98.

Singh NP, McCoy MT, Tice RR and Schneider EL (1988). A simple technique for quantitation of low levels of DNA damage in individual cells. Exp. Cell. Res. 175: 184-191.

Tan EK, Chan DK, Ng PW, Woo J, et al. (2005). Effect of MDR1 haplotype on risk of Parkinson disease. Arch. Neurol. 62: 460-464.

Taniguchi S, Mochida Y, Uchiumi T, Tahira T, et al. (2003). Genetic polymorphism at the 5' regulatory region of multidrug resistance 1 (MDR1) and its association with interindividual variation of expression level in the colon. Mol Cancer Ther. Dec 12: 1351-9.

Tielemens E, van Kooij R, te Velde ER, Burdorf A, et al. (1999). Pesticide exposure and decreased fertilization rates in vitro. Lancet. 354: 484-485.

World Health Organization (2010). WHO laboratory manual for the examination of human semen and semen-cervical mucus interaction. 5th edn. WHO Press, Switzerland. 